\title{
Teaching English as a Second Language at a University in Colombia That Uses Virtual Environments: A Case Study
}

\author{
Enseñanza del inglés como segunda lengua en una universidad de Colombia que utiliza \\ ambientes virtuales: Estudio de caso
}

\section{Ensino do Inglês como segunda língua numa universidade Colombiana que usa ambientes virtuais: Estudo de Caso}

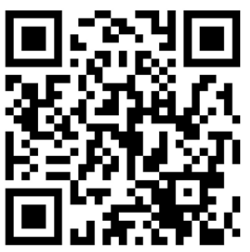

\author{
Sandra Vega-Carrero' \\ University of Kansas \\ Fulbright Scholar \\ Lawrence, Estados Unidos \\ svegacarrero@gmail.com \\ http://orcid.org/0000-0001-9050-2212 \\ Manuel Alejandro-Pulido ${ }^{2}$ \\ University of Kansas \\ Fulbright Scholar \\ Lawrence, Estados Unidos \\ manuelpulidov@gmail.com \\ (iD) http://orcid.org/0000-0002-4184-0300 \\ Nancy Esther Ruiz ${ }^{3}$ \\ Corporación Universitaria Adventista \\ Medellín, Colombia \\ nancyesterr@yahoo.com \\ http://orcid.org/0000-0002-6534-7908
}

\begin{abstract}
${ }^{1}$ She holds a Bachelor's degree in Basic Education from the Universidad Autónoma de Bucaramanga [Autonomous University of Bucaramanga] and a Master's Degree in Education with a major in Educational Technology from the University of Kansas. She worked at the University of Kansas as cultural ambassador, teacher, and creator of multimedia material. She also worked at teh Adventist University of Colombia in teaching English as a second language, Didactics and Literature. At the same time, she developed online courses to train English teachers. Sandra is interested in everything related to online learning and the development of multimedia resources for academic purposes. For this reason, she worked as a consultant for the United Nations and the Inter-American Development Bank, producing and coordinating the creation and implementation of online courses.

${ }^{2} \mathrm{He}$ is an economist from the Universidad Nacional de Colombia [National University of Colombia]. He holds a Master's Degree in Economics from the National University of Colombia, and is currently a PHD candidate at the University of Kansas. He has worked as a university lecturer, and as a teacher of macroeconomics and econometrics. Likewise, he has worked for the Ministry of Finance and Public Credit in Colombia, as well as for the Development Research Center attached to the Faculty of Economics at the National University of Colombia.

${ }^{3}$ She holds a Bachelor's degree in Educational Administration at the University of San Buenaventura. She is specialist in Personalized Education at the Catholic University of Manizales. She also holds an Associate's degree at the Universidad Tecnológica de Bolívar [Technological University of Bolívar] with the paper "Cartagena, Vital Knowledge of the Caribbean." She is certified by the University of Antioquia in "Design of Virtual Learning Objects." She is also certified by the Adventist University Corporation in "Operation of the Moodle Platform and Use of Web 2.0 Tools." She holds a diploma in TDI (Teacher Development Interactive) at the Hunter College of New York in agreement with the Colombia National Service of Learning (SENA), Pearson, Systems and Training, and the Secretariat of Education [Secretaría de Educación] of the Department of Antioquia. She currently works as a teacher for the Corporación Universitaria Adventista de Colombia [Adventist University Corporation of Colombia], and gives her selfless work in the Women's Initiative for Peace Association, in the Corporación Comunidad la Vid [the Vine Community Corporation]. She worked as a teacher of secondary education in two educational institutions: San Carlos and Latin American Gymnasium. He was a teacher of New Technologies and bilingualism in secondary school at Fe y Alegría School and Manuela Beltran Auxiliary Center for Teaching Service (CASD).
\end{abstract}


doi: http://dx.doi.org/10.15359/ree.21-3.9

URL: http://www.una.ac.cr/educare

CORREO: educare@una.cr

Recibido 2 de abril de 2016 • Corregido 21 de junio de 2017 • Aceptado 3 de agosto de 2017 Received 2 de abril de 2016 • Revised 21 de mayo de 2017 • Accepted 3 de agosto de 2017 Recebido 2 de abril de 2016 • Revisado 21 de mayo de 2017 • Aprovado 3 de agosto de 2017

\begin{abstract}
This article presents the results of a research study conducted with college students at a University in Colombia that offers an online program of English as a Foreign Language. The goal of this study was to understand the students' perceptions. It mainly responded to the following research questions: Why do these students participate in an EFL online program? What are their perspectives about the methodology used in the virtual environment to learn a second language? What are their perspectives about the environmental factors involved in the learning process? And how are technical factors influencing the online learning process? This study used a qualitative research method. A questionnaire-based survey method was used for data collection. The population participating in this research was selected randomly, and the participants were promised anonymity prior to the completion of the questionnaire. It was found that online students master technology while learning in a virtual environment. In addition, students perceived that, with the activities promoted in the e-learning environments, they increased their vocabulary skills. Also their grammar and reading skills tended to improve considerably. However, students perceived that the interaction between them and their instructors should increase, so they would have the possibility of answering their questions and strengthening their speaking and writing skills.
\end{abstract}

Keywords: English as a foreign language; online education; students' perceptions; adult education.

Resumen: Este artículo presenta los resultados de una investigación realizada a estudiantado universitario de una universidad de Colombia que ofrece un programa de inglés como lengua extranjera en un ambiente virtual. El objetivo de este estudio es comprender sus percepciones. Responde principalmente a las siguientes preguntas de investigación: ¿Por qué este estudiantado participa en EFL - programa en línea? ¿Cuáles son sus perspectivas sobre la metodología utilizada en el entorno en línea para aprender un segundo idioma? ¿Cuáles son sus perspectivas sobre los factores ambientales involucrados en el aprendizaje proceso, y cómo son los factores técnicos que influyen en el proceso de aprendizaje en línea? Este estudio utilizó un método de investigación cualitativa. Se recopiló información con un método de encuesta basado en cuestionarios para la recopilación de datos. La población que participó en esta investigación fue seleccionada al azar, y se le prometió el anonimato. Se encontró que el estudiantado en línea mejora sus habilidades tecnológicas, mientras aprende en un entorno virtual. Además, perciben que con las actividades promovidas en el aula virtual, aumentó su capacidad de vocabulario. También sus habilidades de gramática y lectura mejoraron considerablemente. Sin embargo, consideran que la interacción entre estudiantes y su personal instructor debe aumentar para ofrecer la posibilidad de responder a sus inquietudes ampliamente y que el fortalecimiento de sus habilidades de habla y escritura se lleve a cabo.

Palabras claves: Inglés como lengua extranjera; educación en línea; percepción de estudiantes; educación de personas adultas.

Resumo: Este artigo apresenta os resultados da pesquisa realizada pelos estudantes universitários, de uma universidade na Colômbia, que oferece Inglês como idioma estrangeiro em um ambiente virtual. O objetivo deste estudo é compreender suas percepções. Responde principalmente às 


\begin{abstract}
seguintes questões de pesquisa: Por que os estudantes participam em EFL - programa virtual? Quais são os seus pontos de vista sobre a metodologia utilizada no ambiente on-line para aprender uma segunda língua? Quais são as suas perspectivas sobre os fatores ambientais relacionados com processos de aprendizagem, e como são os fatores técnicos que influenciam no processo de aprendizagem virtual? Este estudo utilizou um método de investigação qualitativa. As informações foram conseguidas através de um método de pesquisa com base em questionários para obter os dados. A população participante desta pesquisa foi aleatoriamente selecionada, e mantida no anonimato. Constatou-se que os estudantes virtuais melhoram suas habilidades tecnológicas ao mesmo tempo que aprendem num ambiente virtual. Ao mesmo tempo, percebem aumentar seu vocabulário com as atividades promovidas na sala de aula. Também suas habilidades gramaticais e de leitura melhoraram consideravelmente. Porém, consideram que a interação entre alunos e instrutores devem aumentar para proporcionar a oportunidade de resolver amplamente suas preocupações e fortalecer suas habilidades faladas e escritas.
\end{abstract}

Palavras chaves: Inglês como idioma estrangeiro; educação virtual; percepção dos estudantes; educação das pessoas adultas.

\title{
Introduction
}

In previous studies, we had focused our interest in exploring the growing process of online education in Colombia. Vega, Piedra, and Cunningham (2015) affirmed that Colombia has 349 active universities, 20,709 active programs (Face to Face-F2F), and 495 online programs. This number is relevant keeping in mind that the Colombian government established in 2010 the law that regulates the online educational system -Decreto 1295 of 2010- (MEN, 2010). This means that in only 6 years the formal Online Education in Colombia has grown significantly fast.

One of the most influential factors associated to this growing process is the influence of the Internet in the whole society. Ministerio Tic (2012) surveyed 1,005 Colombian citizens in 2012 and approximately $80 \%$ of the responses affirmed they utilize the Internet and access it effectively on their own.

Another significant fact that is relevant to this study is the Colombian government's interest on implementing policies that motivate and encourage Colombian citizens to become bilingual, English being the foreign language promoted Vega et al. (2015) affirmed that programs such as Colombia Bilingue (MEN, 2005) and the National Bilingual Program (2004-2019) promote learning of English as a foreign language, and work to increase the communicative competence in English throughout the educational system and strengthen national competitiveness.

Due to extraordinary interest to learn English, the demand of having bilingual instructors in the classroom is high. The government has taken some steps in order to meet this need. For instance, they brought native English speakers as collaborative volunteers/English instructors to the Colombian Public Institutions. They also promote English Summer Camps where around 3,000 ninth graders travel to the United States with the main purpose of learning English through 
doi: http://dx.doi.org/10.15359/ree.21-3.9

URL: http://www.una.ac.cr/educare

CORREO: educare@una.cr

immersion, improving their listening and speaking skills (MEN, 2015); and open new educational programs that prepare Colombian teachers to teach EFL, 15 of them are online (SNIES, 2015).

Since this movement of Online Education in Colombia is relatively new, there are few studies focused on this growing phenomenon. This is why, the researchers decided to dedicate this revision to deepen their understanding of it, and how Colombian-college-students are perceiving it.

It is important to keep in mind that in this study the definition of online education given by Mood (1995), Sherry (1996) and Dabbagh (2007) is used. They agreed that one of the main characteristics of online education is the separation of the teacher and the learner in space and time. Learners should have certain characteristics that would make him/her successful, including: independent, self-motivated, disciplined, self-starter, and goal-oriented.

Furthermore, as stated by Vega et al. (2015) educators have changed their communicative and pedagogical roles. Nowadays they are considered to be facilitators of the teaching and the learning process (Boyd, 2004). "They are no longer perceived as a professor that gives a lecture in the middle of the classroom" (Vega et al., 2015 p. 362) Nowadays, they have a management, advisory and supervisory role (Braun, 2008; Donoghue, Singh \& Dorward, 2001; Hall \& Knox, 2009).

According to studies, there are three vital stages when planning an online course. Firstly, it is crucial to establish the learning goals: "knowing what the purpose of the course is, will lead the instructional designer to choose the most appropriate technological tools" (Vega et al., 2015 p. 363). This will also benefit the student's performance since he will understand: where is he going, and what path can he take in order to be successful.

Secondly, an online course should include different types of activities:"students can read, speak, listen, think deeply, write, and apply their knowledge to solve problems and complete authentic projects" (Berge, 2011, p. 91). In this aspect, multimedia products are vital. According to the 2008 Horizon Report, video is an emerging technology for conventional use for teaching and learning. Instructors are creating videos in an expository way to teach the contents of the course. Audio also has been utilized increasingly in online education through podcasts. Fulgham (2011) explained.

Multimedia producers are increasingly being introduced in EFL online courses through publishers as a package deal when adopting a textbook. Publishers may offer audio, video CD-ROMs and interactive websites to meet the needs of instructors who need content for online courses. (p. 142)

Another type of activity that should be use is collaborative work. Berge (2011) suggested that to overcome the sense of 'isolation', teamwork, collaboration or some type of group work is often assigned. The main reason for team assignments is to accomplish part or all of the learning goals, and replicate authentic work conditions. 
Thirdly, according to Berge (2002) feedback is one of the most important actions that an online course should promote actively. There are different types of feedbacks, which are instructor, student, peers, individual and group feedbacks. Individual feedback is essential to facilitate learning; it allows students to correct their own performance. Peer critique is also important in the learning process. In addition, the students should provide some feedback the instructor and the course (contents, technological tools, schedule of the activities and goals). This will help the approach of the course in the future.

Beside these three important stages, there are also two types of factors that influence the learning process in online courses: environmental and technical factors. There are several environmental factors involved that will determine whether a student is successful or not, including time management skills, supports of others and appropriate schedules. Donoghue, Singh and Dorward quoted by Vega et al. (2001) suggested that "often students spend more time in an online learning environment than face-to-face interactions because of the information that they will have to read and search on the web" (p. 365). Online learners have to manage their day and schedule time for study and participation in online activities. Consequently, the support from others is vital. Most of the time the learners are located at home, therefore every time they enter their online environment, they can face lots of challenges, such as noise, phone calls, kids yelling and so on. Students must find a place free from distractions caused by work, friends, and family members. Their relatives, friends, co-workers and employers should be made aware of and be supportive of the online student's needs by allowing them the freedom to participate actively in their online classes and therefore succeed.

There are also technical factors involved in the learning process, including "sending an email, searching on the Internet, using Windows or Mac, managing Microsoft Office applications, and computer skills (printing, using keyboard, a mouse and so on" (Vega et al., 2015, p. 365). According to different scholars, online learners have to master these skills to succeed in their online course (Boyd, 2004; Majid \& Abazova, 1999; Donoghue, Singh \& Doward, 2001).

For all the above mentioned facts, this study examines the perceptions of EFL-collegestudents in a university of Colombia that uses online environments.

\section{Characteristics of the Study}

\section{Methodology}

This study used a qualitative research method. A questionnaire-based survey method was used for data collection. To ensure the validity and reliability of the survey three experts rated the questionnaire and provided written feedback. In addition, the questionnaire was administered to a small sample during the fall of 2015 semester as a pilot study. The survey was then modified 
doi: http://dx.doi.org/10.15359/ree.21-3.9

URL: http://www.una.ac.cr/educare

CORREO: educare@una.cr

in light of the comments and suggestions of the three evaluators and the results of the pilot study and ensure instrument's validity and reliability. (See Appendix A for questionnaire) Also, basic descriptive analysis using means and standard deviation are used.

The participants were promised anonymity prior to their completion of the questionnaire. However, it included general information of the institutions and participants including: gender, level of the courses, resources available to teachers and students, and assessment methods. The survey included some open questions asking for honest feedback about their experiences and comments on how to improve EFL online courses. The students responded in Spanish, therefore, answers were translated.

\section{Population}

The population that participated in this research was selected randomly. E-mail was sent to several colleges and universities but only one accepted to participate in this study. This university is private and the role of the technology is as a learning management system, which is used to deliver, track, report on and manage learning content, learner progress, and learner interactions through Moodle. E-mails were sent to first and fifth semester students instructing them to click on a link and complete the survey. Twenty-one students accepted to participate and at the end of the study they entered into a $\$ 50$ raffle. Table 1 provides a detailed description of the research sample.

Tabla 1: Description of the study sample

\begin{tabular}{|c|c|c|c|}
\hline Independent Variables & Categories & N. & $\%$ \\
\hline \multirow{2}{*}{ Gender } & - Female & 17 & 82 \\
\hline & - Male & 4 & 18 \\
\hline \multirow{2}{*}{ English Level } & 1 & 8 & 36 \\
\hline & 5 & 13 & 64 \\
\hline \multirow{4}{*}{ Computer Literacy } & - Beginner & 4 & 18 \\
\hline & - Good & 7 & 32 \\
\hline & - Very Good & 10 & 50 \\
\hline & - Advance & 0 & 0 \\
\hline \multirow{3}{*}{ Occupation } & . Full-time job & 19 & 90 \\
\hline & · Part-time job & 0 & 0 \\
\hline & - Home-mother/father & 2 & 10 \\
\hline
\end{tabular}

Basic descriptive analysis, using means, and standard deviation were used to analyze the student population sample. No attempt is made to use formal statistical significance or sample size techniques to infer that the results of this study represented larger populations. 


\section{Purpose}

The goal of this study is to understand the perceptions of college-EFL-students in an online environment within Colombia. The questionnaire gave the learners an opportunity to discuss opinions of their interactions. This information is useful in designing future online EFL courses. The following are the specific research questions/objectives to be answered:

1. Why do these students participate in EFL - online programs?

2. What are their perspectives about the methodology used in the online environment to learn a second language?

3. What are their perspectives about the environmental factors involved in the learning process?

4. How are technical factors influencing the online learning process?

\section{Results and Discussion}

The survey results are presented in four sections, each section responded to the research questions mentioned above.

\section{Why do these students enroll in an EFL online program?}

After analyzing the data from questions number 5, 7 and 17, that ask students about the reasons why they enrolled in an EFL-online course and the place where they use their computers to access the course, it was found that the most frequent response (64\%) of the students affirmed that their main reason was for flexibility of schedule (Table 2) and the second most frequent response (41\%) was because of the ability to do course work at home. This result is reasonable since the $90 \%$ of the students have full time job positions. In addition, question 7 indicated $95 \%$ of the students confirmed that they access the course at home. This implies that they would access to the course at nighttime or early in the morning (Table 3).

The responses on the open-question number 17 regarding this topic, give us a glance on how the online students affirmed the reasons why they chose this modality, making comments such as: "Otherwise it would be almost impossible to learn another language due to my job and all the obligations that I have" "because in this way I can study and work to fulfill my obligations." "I would recommend this learning type to my friend if he / she works and her/his schedule does not allow them to study in a F2F environment." 
doi: http://dx.doi.org/10.15359/ree.21-3.9

URL: http://www.una.ac.cr/educare

CORREO: educare@una.cr

Table 2: Reasons why EFL students enroll in an online course

\begin{tabular}{lcc}
\multicolumn{1}{c}{ Category } & $\mathrm{N}$ & $\%$ \\
\hline Flexibility of schedule & 13 & 64 \\
Ability to do course work at home & 9 & 41 \\
Enjoy online instruction & 7 & 32 \\
Financial Reasons & 2 & 9 \\
Curiosity & 1 & 5 \\
Other (Please describe) & 0 & 0 \\
\hline
\end{tabular}

Table 3: Place to access to the course

\begin{tabular}{lrrrr}
\hline Category & $\mathrm{N}$ & $\%$ & Mean & $\mathrm{ST}$ \\
\hline Home & 20 & 95 & 1.05 & 0.21 \\
Office & 1 & 5 & & \\
\hline
\end{tabular}

\section{What are their perspectives about the methodology used in the online environment to learn a second language?}

Questions number 10,13 and 14 addressed this research inquiry. Number 10 asked about the resources used in the online environment. It was wanted to figure out the tools used in the online environment, therefore it was asked what were the main resources used in the course. It caught our attention that students did not know the name of their LMS. 14\% affirmed that they used Blackboard, and only $41 \%$ used Moodle (LMS of the university). Also $100 \%$ of the students confirmed that they utilized audios and $41 \%$ said that they used video streaming.

The responses presented in Table 4 made us wonder why the answers differ significantly, if all the resources are available in the LMS for all students. They should be using the same elements when taking the online course. 
Table 4: Resources used in the online environment

\begin{tabular}{lcc}
\hline \multicolumn{1}{c}{ Resources } & N & $\%$ \\
\hline Audios & 21 & 100 \\
Emails & 19 & 86 \\
Documents (Word) & 18 & 82 \\
Chat- Real time (Skype) & 17 & 77 \\
Documents (PDF) & 15 & 68 \\
Discussion Board & 11 & 50 \\
Moodle & 9 & 41 \\
PowerPoint Slides & 7 & 32 \\
Animations Flash & 5 & 23 \\
Blackboard & 3 & 14 \\
\hline
\end{tabular}

Question 13 consisted of Likert-type-scale statements that ask about methodology used in the online environment regarding the level of improvement in the interaction between peers, contents, motivation, technology and the quality in their learning experience. Table 5 and 6 below shows, in order, the student's perceptions regarding these interactions in the course.

Table 5: Students' perceptions of the level of general improvement in an online environment

\begin{tabular}{|c|c|c|c|c|c|c|c|}
\hline Question & SD & $\mathrm{D}$ & NC & 1 & $\mathrm{SI}$ & Mean & SD \\
\hline \multicolumn{8}{|l|}{ Part I } \\
\hline Your familiarity with computer technology & 0 & 0 & 2 & 7 & 12 & 4.48 & 0.68 \\
\hline The quality of your learning experience & 0 & 2 & 1 & 10 & 8 & 4.14 & 0.91 \\
\hline The amount of contents & 0 & 1 & 3 & 10 & 7 & 4.10 & 0.83 \\
\hline The motivation to participate in class activities & 0 & 3 & 2 & 7 & 9 & 4.05 & 1.07 \\
\hline
\end{tabular}

Significantly Decreased (SD), Decreased (D), No Change (NC), Increased (I) Significantly Increased (SI).

\section{Part I}

Their familiarity with computer technology rated the highest with a mean of (4.48) followed by the quality of their learning experience with a mean of (4.14). These higher scores correlates to the answer on question 4 which asked about the level of technology-expertise. Figure 1 compares the level of technology expertise between students from first and fifth semester. 50\% of the students on first level indicate that they are beginner in relation to the use of technology, 
doi: http://dx.doi.org/10.15359/ree.21-3.9

URL: http://www.una.ac.cr/educare

CORREO: educare@una.cr

$37 \%$ good and $13 \%$ very good. On the other hand, the fifth-level-students responses show that $71 \%$ of them are very good, and $29 \%$ are good. This can be an indicator of transversal learning. Online students master technology while learning in an online environment.

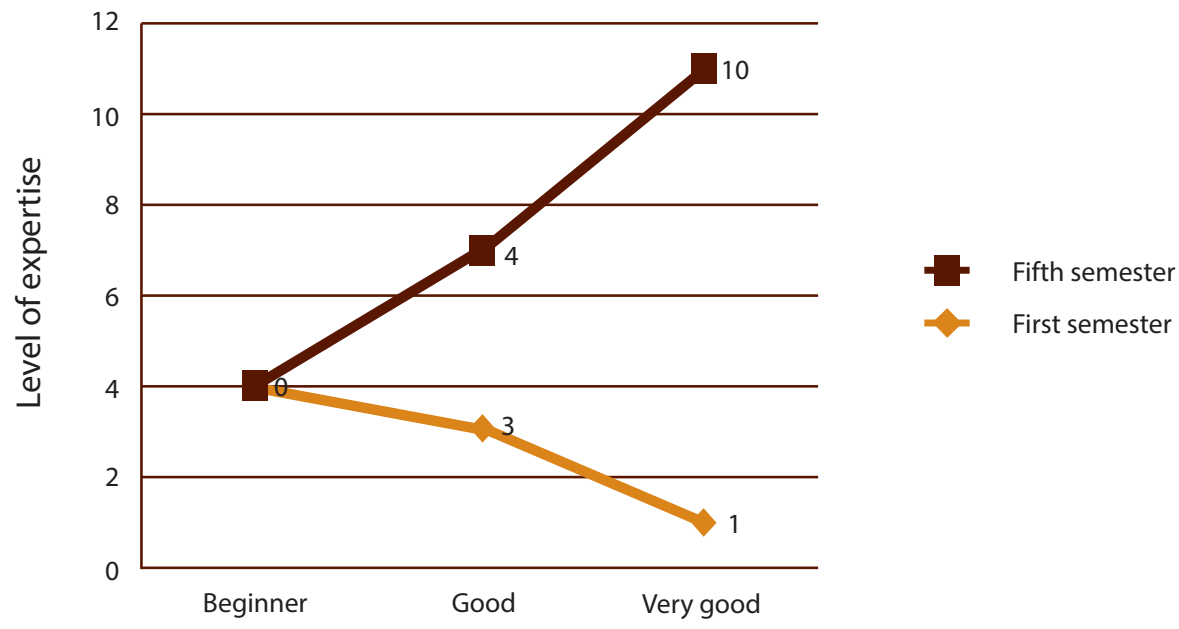

Figure 1: Level of expertise - Technology.

Part II

The second part of question 13 , focuses on the students'perception about this methodology and if it improves or not the amount and quality of interaction between the instructor and their peers. A slight decrease can be evidenced in the improvement of the quality of interactions with other students with a mean of (3.81), and with the instructor with a mean of (3.67). Also the amount of interactions between the participants seems to slightly decrease: the instructor (3.67) and the other students (3.52).

Table 6: Students' perceptions of the level of improvement-interaction in an online environment.

\begin{tabular}{llllllll}
\hline Question & SD & D & NC & I & SI & Mean & SD \\
\hline Part II & & & & & & & \\
The quality of interaction with other students & 0 & 6 & 0 & 7 & 8 & 3.81 & 1.25 \\
The quality of interaction with the instructor & 1 & 5 & 2 & 5 & 8 & 3.67 & 1.35 \\
The amount of interaction with the instructor & 2 & 4 & 0 & 10 & 5 & 3.57 & 1.33 \\
The amount of interaction with other students & 0 & 6 & 3 & 7 & 5 & 3.52 & 1.17 \\
\hline
\end{tabular}

Significantly Decreased (SD), Decreased (D), No Change (NC), Increased (I) Significantly Increased (SI) 
These data can be correlated with some quotes taken from the open-ended section of the questionnaire that ask about how to improve the methodology used in the courses (question 19). Several students suggested the importance of increasing the interaction with the students: "More interaction with the instructor (Skype calls or video streaming), weekly conversations to practice speaking, and strengthen writing and grammar" "There should be more interaction with the instructor to practice our conversational skills", "The online meetings should be more than just once a week, maybe three times a week", "To learn English, there should be more instructor presence to practice and answer questions".

Part III

Question 14 asked the students' perception on how e-learning helped them to improve their EFL skills. Table 7 shows how students believe that e-learning helped them to improve their vocabulary skills with a mean of (4.14), followed by listening and reading with a mean of (3.95), writing (3.90), spelling and grammar (3.86). Also the students' perceptions regarding pronunciation and speaking skills seems to decrease with a mean of (3.76) and (3.71).

Table 7: Students' perception on how e-learning help them to improve their EFL skills

\begin{tabular}{|c|c|c|c|c|c|c|c|}
\hline Skills & SD & D & $\mathrm{NC}$ & I & SI & Mean & SD \\
\hline \multicolumn{8}{|l|}{ Part III } \\
\hline Vocabulary & 2 & 0 & 0 & 10 & 9 & 4.14 & 1.15 \\
\hline Listening & 2 & 1 & 0 & 11 & 7 & 3.95 & 1.20 \\
\hline Reading & 2 & 1 & 0 & 11 & 7 & 3.95 & 1.20 \\
\hline Writing & 2 & 0 & 1 & 13 & 5 & 3.90 & 1.09 \\
\hline Spelling & 2 & 0 & 3 & 10 & 6 & 3.86 & 1.15 \\
\hline Grammar & 2 & 1 & 1 & 10 & 6 & 3.86 & 1.20 \\
\hline Pronunciation & 2 & 2 & 1 & 11 & 6 & 3.76 & 1.26 \\
\hline Speaking & 2 & 0 & 3 & 13 & 3 & 3.71 & 1.06 \\
\hline
\end{tabular}

(Significantly Decreased (SD), Decreased (D), No Change (NC), Increased (I) Significantly Increased (SI)) 
doi: http://dx.doi.org/10.15359/ree.21-3.9

URL: http://www.una.ac.cr/educare

CORREO: educare@una.cr

This last aspect can be also correlated with the open-ended answers given by the students in the final section of the questionnaire that asks how to improve the methodology used in the courses (question 19): "There should be a software that can verify our pronunciation. Ithink this is one of the biggest disadvantages of this course. It only works towards learning theory, grammar and pronunciation"; "They should include more audio and interactive videos"; "The university should include a program similar to Duolingo, to double check our spelling and pronunciation"; "They should have more interaction to improve our speaking"; and "There should be a way to improve our speaking in real-time and online."

\section{What are their perspectives about the environmental factors involved in the learning process $(8,9,16)$}

As said in the framework, there are some environmental factors that would determine whether a online student is successful or not. Those factors included, students characteristics, time management skills, support from others, and convenient schedules. For this reason, questions 8 and 9 asked about students' frequency of access to the course. Table 8 shows that $(41 \%)$ of the students access the online course six hours or more per week. Students rated (18\%) in each of the other choices: five, four, and three hours. In addition, a student rated that he accesses the online course only two hours a week.

Table 8: Frequency - access per week

\begin{tabular}{ccc}
\hline Hours per week & $\mathrm{N}$ & $\%$ \\
\hline 6 or more & 8 & 41 \\
5 & 4 & 18 \\
4 & 4 & 18 \\
3 & 4 & 18 \\
2 & 1 & 5 \\
1 & 0 & 0 \\
\hline
\end{tabular}

After seeing the information in general, we wanted to compare the percentages of each of the semesters and the students'frequency of access per week. We found that most of the students in the first semester access the course six or more hours per week (63\%), compared to (20\%) of fifth level students who access the same amount of times in a week, as it is shown (Figure 2). 


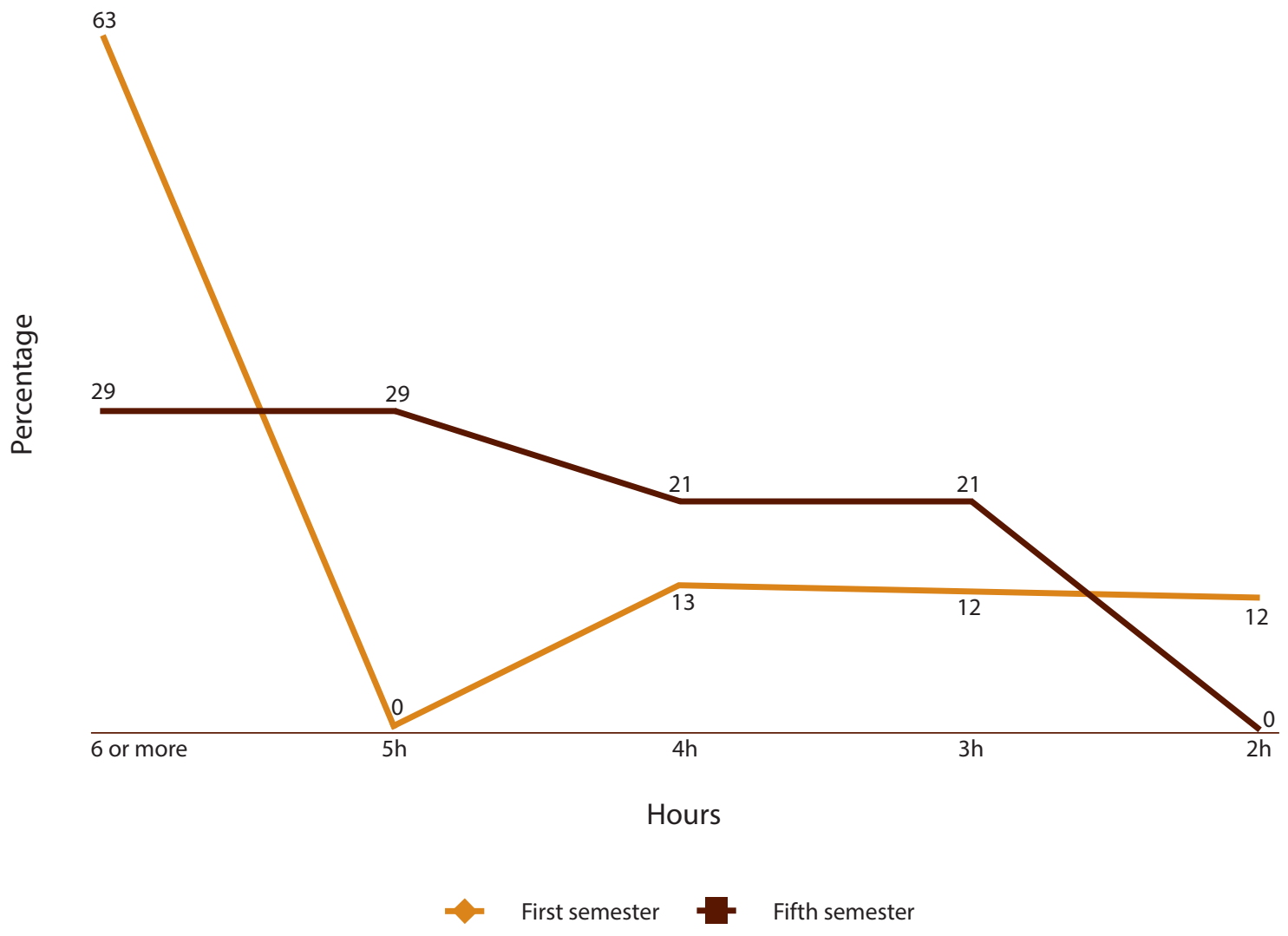

Figure 2. Percentage of frequency access per week by semester.

However, we wanted to deepen this research question. Therefore, we asked students to estimate their weekly time spent working on the EFL course (question 9). Table 9 shows the number of hours reported by first semester (I-SS) versus fifth semester (V-SS) students. It was found that there was more variation in students reading through announcements compared to other tasks (I-SS SD=10 and V-SS SD=3.7). Also, the task that students spend less time working with was on dealing with technology issues (including password and downloading problems) each semester presented a mean of (1.00). If added, the total amount of hours, I-SS spend the same amount of hours as V-SS: 15 hours working on the course. This information varies from the responses on question 8 , that were analyzed above. 
doi: http://dx.doi.org/10.15359/ree.21-3.9

URL: http://www.una.ac.cr/educare

CORREO: educare@una.cr

Table 9: Weekly time spent working on the EFL course

\begin{tabular}{|c|c|c|c|c|c|c|c|c|}
\hline & $\begin{array}{l}\text { Min Value } \\
\text { I-SS }\end{array}$ & $\begin{array}{l}\text { Max Value } \\
\text { I-SS }\end{array}$ & A & SD & $\begin{array}{l}\text { Min Value } \\
\text { V-SS }\end{array}$ & $\begin{array}{l}\text { Max Value } \\
\text { V-SS }\end{array}$ & A & SD \\
\hline Reading through the announcements & 1 & 30 & 5 & 10 & 0 & 14 & 3 & 3.7 \\
\hline $\begin{array}{l}\text { Reading and posting to the } \\
\text { discussion board }\end{array}$ & 0 & 5 & 2 & 1.8 & 1 & 3 & 2 & 0.80 \\
\hline Assignments & 2 & 7 & 4 & 2.1 & 1 & 24 & 5 & 6 \\
\hline $\begin{array}{l}\text { Familiarizing yourself with the course } \\
\text { documents }\end{array}$ & 1 & 4 & 3 & 1.1 & 1 & 12 & 4 & 3.20 \\
\hline $\begin{array}{l}\text { Time spent dealing with technology } \\
\text { issues (password, downloading } \\
\text { problems, etc) }\end{array}$ & 0 & 4 & 1 & 1.3 & 0 & 4 & 1 & 1.8 \\
\hline TOTAL & & & 15 & & & & 15 & \\
\hline
\end{tabular}

I-S (First Semester Students) V-S (Fifth Semester Students) A (Average) SD (Standard Deviation)

This research question focuses on the environmental factors involved in the learning process and how they will determine whether a student is successful or not. We wanted to ask the students for the environmental factors that most contributed to their negative or positive perception of the course (question 16). We classified their responses in three categories: students' characteristics, time management skills, and convenient schedules. The only factor that was not included on the students' responses was the support from others. Table 10 shows some of the open-responses given by the students.

Table 10: Environmental factors that influence students' success

\begin{tabular}{ll}
\hline Environmental Factor & Open-ended responses \\
\hline Students' Characteristics & "If there is interest in learning by the student, then success is achieved"; "If you are \\
dedicated and if you want to learn, the online course can be successful"; "I must improve \\
my discipline to study in an online environment"; "You must be very disciplined to take \\
an online course, because nobody will be reminding you that you have to go to the class"; \\
"Ifyou want to be successful you have to be autonomous and self-learner"
\end{tabular}




\section{Students' perspectives about the technology factors impacting their experience with the EFL-online course}

On the first section of this analysis, we found out that the population studied mastered technology while learning in an online environment. Therefore we wanted to analyze the data collected on questions 11 and 12 that asked if technology problems (forgetting passwords, unexpected screen changes, inaccessible links, network failure, data loss, software errors) play a role such as impacting the students' experience with the EFL-online course, and how much impact does the professor's knowledge of technology have on success or nonsuccess of the course.

Table 11 shows that $(70 \%)$ of the students considered that technology problems can cause some impact in the learning process with a mean of (1.81). In addition, students rated the instructor's technology knowledge as a factor of great impact with a mean of (2.40) and a standard deviation of (0.59).

Table 11: Role of technology in the learning experience

\begin{tabular}{lrrrrrrrrr}
\hline & \multicolumn{3}{c}{ No Impact } & \multicolumn{3}{c}{ Some Impact } & Great Impact & \multirow{2}{*}{ Mean } & SD \\
\cline { 2 - 7 } & $\mathrm{N}$ & $\%$ & $\mathrm{~N}$ & $\%$ & $\mathrm{~N}$ & $\%$ & & \\
\hline Q.11 Technology Problems & 5 & 21 & 15 & 70 & 1 & 5 & 1.81 & 0.50 \\
Q.12 Instructor's Technology Knowledge & 1 & 5 & 8 & 38 & 12 & 61 & 2.40 & 0.59 \\
\hline
\end{tabular}

\section{Limitations of the Study}

As with any study, there were limitations that may have affected the outcomes of this research. The major factor was the response rate. A larger sample size would have been needed for generalization and transferability. Also, demographic information on the population would have been important to obtain.

\section{Conclusions and Recommendations}

As already mentioned, the focus of this study is to understand the perceptions of college-EFL-students in an online environment within Colombia, there is not attempt to make generalizations.

This paper reports on four main topics of students' perceptions: Why do they learn English in online environments, what do they think about the teaching-learning methodologies, what are their perspectives about the environmental factors and finally, if technology-problems and instructor's technology knowledge affect students' success. 
doi: http://dx.doi.org/10.15359/ree.21-3.9

URL: http://www.una.ac.cr/educare

CORREO: educare@una.cr

First, it was evident that the main reason why college students participate in EFL online courses is because of its flexibility of schedule. The majority of students stated that they work in full-time job positions, therefore the online environment is very convenient.

Second, their perceptions about the methodology in the online environment to learn a foreign language. It was found that online students master technology while learning in an online environment. In addition, students perceived that with the activities promoted in the e-learning environments they increase their vocabulary capacity. Also their grammar and reading skills tend to improve considerably. However, students perceived that the interaction between them and their instructors should increase so they would have the possibility of answering their questions and strengthening their speaking and writing skills. Another aspect that should be enhanced is the inclusion of more interactive videos or audios that can help them strengthen their pronunciation, including a software that can recognize their voice and verify their pronunciation.

Third, students characterized three types of environmental factors that will influence the students' success: students' characteristics (autonomous, self-learners, disciplined), time management skills (organized, manage time, avoid procrastination), and flexibility of the course (curriculum is available 24/7, this allow them to study while fulfilling their obligations). The only aspect they did not mention was the importance of the support from others.

Fourth, it was found that students believe that technology problems including networking failure, software errors, and data loss, cause some impact in the learning experience. In addition, they considered that the instructor's technology knowledge causes great impact on the success of the course.

For further research, it is important to include in the questions more details about the weekly time spent working on the online course that is focused on EFL activities, including speaking, reading, listening and writing. In addition, it would have been nice to ask for more details on the experience between the students and the teacher in regard to her/his technological knowledge.

\section{References}

Majid, S., \& Abazova, A. F. (1999). Computer literacy and use of electronic information sources by academics: A case study of International Islamic University Malaysia. Asian Libraries, 8(4), 100-111. doi: https://doi.org/10.1108/10176749910275867

Berge, Z. L. (2002). Active, interactive, and reflective eLearning. The Quartely Review of Distance Education, 3(2), 181-190. Recuperado de http://www.acousticslab.org/dots sample/ module4/Berge2002 ActivelnteractiveReflectiveLearning.pdf 
Berge, Z. L. (2011). Pedagogy of online instruction. In M. F. Shaughnessy, \& S. Fulgham (Eds.), Pedagogical models: The discipline of online teaching (pp. 87-96). New York: Nova Science Publishers.

Boyd, D. (2004). The characteristics of successful online students. New Horizons in Adult Education and Human Resource Development, 18(2), 31-39. doi: https://doi.org/10.1002/nha3.10184

Braun, T. (2008). The perceptions and attitudes of Online Graduate students. Journal of Technology and Teacher Education, 16(1), 63-92.

Dabbagh, N. (2007). The online learner: Characteristics and pedagogical implication. Contemporary Issues in Technology and Teacher Education, 7(3), 217-226. Retrieve from https://citejournal.s3.amazonaws.com/wp-content/uploads/2014/05/v7i3general1.pdf

Dabbagh, N., \& Bannan-Ritland, B. (2005). Online learning: Concepts, strategies, and application. Upper Saddle River, NJ: Prentice Hall.

Donoghue, J., Singh, G., \& Dorward, L. (2001) Virtual Education in Universities: A Technological imperative. British Journal of Education Technology, 32(5), 511-523. doi: https://doi. org/10.1111/1467-8535.00221

Fulgham, S. (2011). Effective learning with video, audio, and simulations. In M. F. Shaughnessy, \& S. Fulgham (Eds.), Pedagogical Models: The Discipline of Online Teaching (pp. 141-152). New York: Nova Science Publishers.

Hall, D., \& Knox, J. (2009). Issues in education of TESOL teachers by distance education. Distance Education, 30(1), 63-85: https://doi.org/10.1080/01587910902845964

Ministerio de Educación Nacional (MEN). (October-December, 2005). Bases para una nación bilingüe y competitiva. Al Tablero, No. 37. Retrieve from http://www.mineducacion.gov. co/1621/article-97498.html

Ministerio de Educación Nacional (MEN). (2010). Decreto No. 1295 April 20 th 2010. Retrieve from http://www.mineducacion.gov.co/1621/articles-229430 archivo pdf decreto1295.pdf

Ministerio de Educación Nacional (MEN). (November, 4, 2015) Más de 3000 estudiantes de noveno grado harán parte de los campos de inmersión en Inglés. CVNE. Retrieve from www.mineducacion.gov.co/cvn/1665/w3-article-354625.html

Ministerio Tic. (November, 20, 2012) Estadísticas de uso de internet en Colmbia. El Ministerio TIC presentó las cifras más recientes en mateira de acceso y uso. Corporación Colombia Digital. Retrieve from http://colombiadigital.net/actualidad/noticias/item/4087estad\%C3\%ADsticas-de-uso-de-internet-en-colombia.html 
doi: http://dx.doi.org/10.15359/ree.21-3.9

URL: http://www.una.ac.cr/educare

CORREO: educare@una.cr

Mood, T. A. (1995). Distance education: An annotated bibliography. Englewood Cliffs, NJ: Libraries Unlimitated.

Fulgham, S. (2011). Effective learning with video, audio, and simulations. In M. F. Shaughnessy, \& S. Fulgham (Eds.), Pedagogical Models: The Discipline of Online Teaching (pp. 141-152). New York: Nova Science Publishers.

Sherry, L. (1996). Issues in Distance Learning.International JournalofEducationTelecommunication, 1(4), 337-365, Retrieved from http://ldt.stanford.edu/ leemba/ldt/resources/issues in distance learning.htm

SNIES. (2015). Búsqueda de programas de instituciones de educación superior. Retrieve from https://snies.mineducacion.gov.co/consultasnies/programa

Vega, S., Piedra, M., \& Cunningham, C. (2015). Perceptions of EFL-College-students in online environments in Colombia. In S. Carliner, C. Fulford, \& N. Ostashewski (Eds.), Proceedings of EdMedia: World Conference on Educational Media and Technology 2015 (pp. 359-367). Association for the Advancement of Computing in Education (AACE). Recuperado de $\quad$ http://webcache.googleusercontent.com/search?q=cache:82mUD 3JTCwJ:www. learntechlib.org/d/151302+\&cd=1\&hl=es\&ct=clnk 
doi: http://dx.doi.org/10.15359/ree.21-3.9

URL: http://www.una.ac.cr/educare

CORREO: educare@una.cr

\section{Appendix A \\ Questionnaire}

Although participation may not benefit you directly, we believe that the information obtained from this study will help us gain a better understanding of educational technology. Your participation is solicited, although strictly voluntary. Your name will not be associated in any way with the research findings.

\section{Part I}

1. Age

2. Gender: Female __ Male

3. English Level: First ___ Fifth

4. I would rate my level of computer expertise as: Beginner _ Good _ Very good _ _ Advanced _

5. Which of the following options describes your motive for enrolling in an EFL - online course? (Check all that apply)
a. Flexibility of schedule
b. Ability to do course work at home
c. Curiosity
d. Enjoy online instruction e. Financial Reasons
f. Other (Please describe)

6. How easy/difficult was it for you to use technology to participate in this course? Easy __ Somewhat Easy __ Somewhat Difficult__ Difficult

7. Where did you most frequently use a computer for this course? Home _ Work __ Othe _ If other, specify:

8. On average, regardless of whether you posted a message or not, how often did you access the course Website each week? a. Once a week _ b. Twice a week_ c. Three times a week__ d. Four times a week_ e. Five or more times a week

9. Estimate your weekly time spent working on one course: Weekly time spent with the EFL online course Reading through the announcements Reading and posting to the discussion board Posting/assignment Familiarizing yourself with the course documents Time spent dealing with technology issues (password, downloading problems...) TOTAL

\section{Part II}

10. What were some of the applications used in your online courses? (Check all that apply) Word files _ Video streaming __ PDF files___ Discussion Board _ Flash media or any type of animation __ Real time chat room PowerPoint Email Audios Other

11. Did technology problems play a role in impacting your experience with the EFL- online course?
a. No Impact
b. Some Impact
c. Great Impact

12. How much impact does the professor's knowledge of technology have on success of the EFL-online course?
a. No Impact
b. Some Impact
c. Great Impact 
doi: http://dx.doi.org/10.15359/ree.21-3.9

URL: http://www.una.ac.cr/educare

CORREO: educare@una.cr

\section{Part III}

13. For each of the statements below, please indicate the level of Improvement

\begin{tabular}{l}
\hline Decreased Somewhat increased No change Somewhat increased Increased \\
The amount of interaction with other students \\
The quality of interaction with other students \\
The amount of interaction with the instructor \\
The amount of contents \\
The quality of your learning experience \\
The motivation to participate in class activities \\
Your familiarity with computer technology
\end{tabular}

\section{Part IV}

For each of the statements below, please indicate the extent of your agreement or disagreement

14. E-learning helped me to improve my:

\begin{tabular}{lccccc}
\hline & Strongly disagree & Disagree & No change & Agree & Strongly agree \\
\hline Listening skills & - & - & - & - \\
Speaking skills & - & - & - & - \\
Reading skills & - & - & - & - \\
Writing skills & - & - & - & - \\
Pronunciation & - & - & - & - \\
Spelling & - & - & - & - \\
Grammar & - & - & - & - \\
Vocabulary & - & - & - & -
\end{tabular}

\section{Part V}

15. For each of the statements below, please indicate the extent of your agreement or disagreement

\begin{tabular}{|c|c|c|c|c|c|}
\hline & Strongly Disagree & Disagree & Neutral & Agree & Strongly Agree \\
\hline I enjoyed the online course & & & & & \\
\hline $\begin{array}{l}\text { Even though we were not physically together in a traditional } \\
\text { classroom. I still felt like I was part of a group in the online course. }\end{array}$ & & & & & \\
\hline The online course stimulated my desire to learn & & & & & \\
\hline An online course allows for social interaction & & & & & \\
\hline
\end{tabular}


doi: http://dx.doi.org/10.15359/ree.21-3.9

URL: http://www.una.ac.cr/educare

CORREO: educare@una.cr

\section{Part VI}

16. For each of the statements below, please indicate the extent of your agreement or disagreement

\begin{tabular}{|c|c|c|c|c|c|}
\hline & Strongly Disagree & Disagree & Neutral & Agree & Strongly Agree \\
\hline E-learning is less convenient for me than face to face learning & & & & & + \\
\hline $\begin{array}{l}\text { E-learning makes English learning more effective; because it } \\
\text { integrates all forms of media, print, audio, video and animation }\end{array}$ & & & & & \\
\hline $\begin{array}{l}\text { I feel more confident when I used English online than when } \\
\text { I use it in a face to face environment. }\end{array}$ & & & & & \\
\hline E-learning helps me use time effectively & & & & & \\
\hline I benefit from the feedback given by my instructor & & & & & 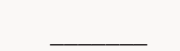 \\
\hline E-learning gives me access to authentic second language materials & & & & & \\
\hline
\end{tabular}

\section{Part VII}

17. Would you rate your experiences to date with this course as: Successful _ Not Successful

If successful, what aspect of the course most contributed to its success?

If not successful, what aspect of the course was most problematic?

18. If a friend asked, would you recommend taking an EFL online course? Why or Why not? Please explain

19. If offered the opportunity would you take another online course?

20. I have the following suggestions for improving this course: 